\title{
Political Hunger Strikes in History of Tuva as a Form of Struggle for Democratic Rights and Freedoms
}

\author{
Oksana Oiun* \\ Tuvan State University \\ 36 Lenin Str., Kyzyl, Republic Tuva, 667000, Russia
}

Received 15.09.2016, received in revised form 03.07.2017, accepted 12.07.2017

This article deals with the analysis of the first political hunger strikes in the history of Tuva that were initiated and organized by representatives of the scientific and creative intelligentsia in 1991 and the political elite in 2007.

The research topic is relevant not only due to the interest of a historian to study the phenomenon of political hunger strikes that are not peculiar to the mentality of Tuvinian nomads who did not previously live under the democratic regime, but also due to the necessity to introduce archival materials into the scientific discourse.

The article examines the reasons for the hunger strikes caused by the political crisis in the Republic, the inability of the authorities to find a compromise with ideological adversaries and to establish a dialogue with the society. The position of the opposition and the current executive authority is also analyzed. The article also studies a social composition of participants in political hunger strikes, their goals and tasks. The consequences of political hunger strikes for its participants are revealed. For example, when the participants of the political hunger strikes in 1991, as well as their wives who lost their jobs survived thanks to the clan system of mutual help, mutual assistance of relatives and friends, which is characteristic of the Tuvinian traditional society. In 2006-2007, in the conditions of the political crisis in Tuva, political parties fulfilled their function of being a mediator between the society and the authorities bringing the people's aspirations to the executive power. The authorities have learnt a lesson from the political hunger strikes, which implied that for the normal functioning of the state's vital activity, it is necessary to take into account not only the opinion of the majority that was formed into a public opinion, but also into an opinion of the minority expressed by representatives of the creative, scientific and political elites.

Keywords: political hunger strike, Republic of Tyva, Tuvinian nomads, opposition.

DOI: 10.17516/1997-1370-0108.

Research area: theory and history of culture.

A political hunger strike is a kind of struggle for one's ideals, a goal for which a person refuses to eat in protest, to put guilt trip on others for what is happening. For the sake of this, the hunger strikers are ready to destruct many stereotypes, to lose their social status, to blur their social roles. For people who live in a democratic society for centuries, political hunger strikes are not

(C) Siberian Federal University. All rights reserved

* Corresponding author E-mail address: oun.oksana@mail.ru 
nonsense, while for Tuva, a traditional society is a kind of indicator of the political development of society, which actualizes the study of the history of political hunger strikes held in Tuva in 1991, 2007.

In the modern historical science of Tuva, some aspects of the studied topic, specifically the 1991 political hunger strike, are analyzed in a monograph of Z.Iu. Dorzhu, O.P. Oiun "Multiparty system in Tuva: genesis and formation (the 90's of the $20^{\text {th }}$ - beginning of the $21^{\text {st }}$ century)." Nevertheless, it should be noted that the problem of political hunger strikes was not the object of a purposeful, special scientific study, many archival materials, personal documents and materials of participants in the hunger strikes, their memories have not been introduced into the scientific discourse, while it is all of scientific interest and increases the theoretical and practical significance of the articles, which analyze the reasons, results and consequences of political hunger strikes.

Tuva is a kind of border region that is interesting and important from the point of view of geopolitics, where the ancestors of Tuvinian nomads lived under the influence of Turks, Uighurs, Mongols and Manchus for centuries... As a result of centuries-old assimilation of peoples and cultures, the Tuvan nation has formed. For the Tuvinian nomads, such concepts as democratic rights and freedoms became known only in the first quarter of the $20^{\text {th }}$ century, when in 1921 a sovereign state the Tuvan People's Republic was formed. Participation of the people in the governance of the state, in the political life of the country was an innovation. Since 1944, Soviet Tuva joined the effective modernization process of building socialism very quickly.

In the 90 's of the $20^{\text {th }}$ century, together with the collapse of the great power of the USSR, everything that has been built for decades collapsed. After that there followed a period of breaking of the Soviet forms of life and the economic and political structure, which led to social cataclysms and transformation of the existing system of values.

For Tuva, this period turned out to be particularly difficult, since the crisis here took an acute form. During the years of Soviet power, 92 state farms that generously subsidized by the state were created instead of many thousands of small and large arat farms. With the termination of subsidies, large farms began to collapse, livestock and equipment were given to private hands, and the collective farms were virtually disbanded (Indicators of social, 1993).

It should be noted that the main feature of the agrarian reform in Tuva was the ban on private ownership of land, despite the fact that in 1990 the law on the peasant (farm) economy was adopted, which provided for the liquidation of collective farms and the introduction of private ownership of land. This feature was associated with the traditional livestock breeding of the Tuvinians, when the cattle were kept at grass, where pastures were passed from generation to generation, although they were not the private property of the clans.

The cost of living in Tuva increased in 1991 due to the rise of prices, for food - by 16.1 times, prices for household services - by 21.9 times, tariffs for communication services - by 36.9 times, transport - by 32.9 times, housing and communal services - by 30.5 times. The level of real incomes of the Tuvinian population decreased by $30 \%$. The average incomes of 79.7 $\%$ of the republic's population were below the subsistence minimum. The property division and differentiation of the population in terms of income are increasing. $50.6 \%$ of the population turned out to be in a difficult condition. For them, payment for labour, pensions and allowances were the main and sometimes the only source of income (Balakina, 1996). 
In the conditions of the economic crisis, the housing problem has become more acute. If we proceed from the average Russian standards, 34.5 $\%$ of families required housing in Tuva.

From the speech of the Khural's deputy of Kyzyl V.A. Vereshchagin (a doctor) "On health of the population" at the session of the Supreme Council, "the hospitals of Kyzyl with nursing staff have faced extreme difficulties. The staffing level is $60 \%$, and we cannot provide a full load to the operating rooms due to the lack of operating nurses. We need to open two specialized departments of paediatric surgery and thermal trauma, but there is not a single nurse. A sufficient number of paramedics and nurses graduate from the medical school produces, but there is no chance for them to stay in Kyzyl because of the lack of housing. And in the regions, the nursing staff cannot find a job in their specialization" (Address to the people's deputies). This period is well characterized by the memoirs of one of the leaders of the "Committee of the Homeless" and a participant in the political hunger strike A.Ch. Ashak-oola (PhD in History, Associate Professor of Tuva State University), "It was a period when people questioned the reasons of social disorder, when the minority has several apartments, and the majority live and huddle in barracks and huts, why the authorities have privileges, but others do not (coupon system, shops, resorts, etc.)" (Doržu, Oiun, 2015: 42).

In such conditions, on January 28, 1991, in the building of the Republican Scientific and Methodological Centre of Folk Art, Cultural and Educational Work, A.Ch. Ashak-ool (at that time a researcher at TNIIALI, a father of three children), L.S. Myndrimaa (an employee in the cooperative "Syldys", a father of two children), V.Sh. Saaia (an artist in the circus cooperative "Mazhaalai", a father of two children), A.A. Togaachy (unemployed, a graduate of the Minusinsk cultural enlightenment school, a father of two children) declared a political hunger strike. An organizing committee of the political hunger strike was set up. Its chairman was E.D. Oorzhak (legal consultant of the State Committee for the Protection of Nature of the Tuvan ASSR), cochairman was S.A. Bair (Head of the Department of the RSMC). The organizing committee also included D. Chysynmaa, an employee in the Ministry of Social Welfare, K. Mongush, an employee in Avtoremezavod.

In the history of Tuva it was the very first political hunger strike, which lasted 12 days. The participants published their address in the national media, where they noted that "the hunger strike was organized in protest against the policy pursued by the Chairman of the Presidium of the Supreme Tuvan ASSR, Ch.B. Ondar and the First Secretary of the CPSU Regional Committee G.Ch. Shirshin as the main perpetrators of the curtailment of democratic transformations in the field of social relations, politics, culture, science, and aggravation of interethnic relations" (Spravka o proshedshei..., 1991).

In an address to the people's deputies of the Tuvan ASSR and the communists of Tuva, the organizing committee declared "In the name of and in the interests of the future democratic Tuva, the students, the unemployed and socially disadvantaged part of the youth, young families, the creative intelligentsia and workers, in protest against the political incapacity and shortsightedness of the Chairman of the Supreme Council of the Tuvan ASSR Ch-D.B. Ondar and the first secretary of the Republican Committee of the Party G.Ch. Shirshin declares distrust to them", "under their constant leadership, our republic is now experiencing a deep socioeconomic and political crisis, which, with its consequences, primarily affects the social situation of the poor in the population and the youth... we are experiencing aggravation of national relations, an increase in crime, deepening 
of spiritual fall of society, we lose folk traditions, beliefs and language" (Reference on the political hunger strike in Kyzyl, 1991).

Many applications, telegrams, letters, both collective and individual, as well as the calls have been received in support of politically hungry people. This action received a wide response in the media as: "The act of desperation" in the weekly newspaper Soiuz (Krasnoyarsk), Information in the Siberian newspaper (Novosibirsk), Komsomolskaia Pravda (Moscow), Washington Post (New York), etc.

As a result, the hunger strikers have achieved their goal.

On February 8, 1991, the newspaper "Molodezh' Tuvy" published an "Address to Workers and Youth of Multinational Tuva" by participants and organizers of the hunger strike “...our first preliminary political hunger strike, as life has shown, caused considerable damage to the long-term prestige of both leaders as accomplices of stagnation, as carriers of the syndrome of infallibility. In the course of the political hunger strike, we witnessed the anti-people policy of the CPSU Revolutionary Committee, their arbitrariness, violation of the law - the Press Law, the Law on Public Associations, the gross infringement of human rights, slander and provocative measures against participants in the political hunger strike. Concluding the preliminary hunger strike, we do not complete the struggle for the further democracy and humanization of society" (Obrashchenie k trudiashchimsia..., 1991).

They have kept their word - they continued the struggle for justice: for the restoration of the rights of the repressed, for the opening of the national Tuvinian school No. 9 in Kyzyl, for the revival of spirituality and faith.

What is noteworthy, the next political hunger strike in 2007 was also announced against the policy pursued by the leadership of the Republic of Tuva, now in the person of Sh.D. Oorzhak, the first president of Tuva, the then Chairman of the Government of the Republic of Tuva.

In an address printed in the weekly newspaper "Centre of Asia" on March 30, 2007, signed by candidates for the Legislative Chamber of the Great Khural of the Republic of Tuva (RT) of the second convocation Z.N. Sat, B.K. Balchiiool, S.V. Safrin, V.A. Ushkalov, I.V. Chuchev, deputies of the Legislative Chamber of the Great Khural B.K. Shombun, V.A. Molin, O.A. Sotpa, A. Tamba, V.V. Kysygbai, deputies of the House of Representatives of the Great Khural U.P. Opeiool, L.M. Oorzhak, voters Sh.M. Norbu, U.Sh. Dargan, L.A. Oiun, S.S. Kuular, and the journalist N.M. Antufieva it was said: "Dear voters, today at 17:00 we decided to end the hunger strike that continues for the eleventh day. We believe that our action of peaceful protest against arbitrariness and lawlessness committed by the executive power of Tuva in the elections to the Great Khural has had its effect. Thanks to your support, we managed to draw the attention of the federal authorities and the leadership of the country to the problems of the republic, first of all, to problems of a political nature. The federal center was finally convinced that the government of the republic and its head had completely exhausted the credit of people's trust and today's actions only undermine the authority of the state power. At present, the federal center is taking steps to change the situation in the republic, and the personnel decisions have been prepared, which have been awaited for a long time in Tuva (Obrashchenie uchastnikov..., 2007).

Sh.D. Oorzhak became the first President of the Republic of Tyva in difficult years - the period of transformation of society, when all political parties, movements, all strata of society were represented in the political life of Tuva. It can be stated that the multi-polarity of views was a great achievement in the 90 's of the $20^{\text {th }}$ 
century. By the end of the permanent leadership of Sh.D. Oorzhak as the Chairman of the Government of the Republic of Tuva, the state did not cope with its functions and did not control the situation. In such circumstances, the regional offices of the parties "United Russia" and "Fair Russia" took over and fulfilled certain functions of the state for the stabilization of society, in conditions of the growing protest mood of voters against the 15-year-old permanent rule of the Chairman of the Government of Sh. Oorzhak.

That allowed the participants in the hunger strike to declare: "During the time of our protest the political forces have changed in the republic, the public opinion has finally formed an idea of the need to change the domestic policy, to change the power in Tuva. People began to boldly and openly speak out against arbitrariness and lawlessness, not wanting to put up with the fact that some people are trying to manipulate their opinion and will in their own selfish interests. The consolidation of forces and actions of the leaders of the regional branches of the "Russian Party of Life" and "United Russia" that has taken place these days gives us hope that in the very near future the crisis of power in our republic will be successfully resolved. It was these factors and circumstances that influenced our decision to stop the hunger strike." The political hunger strike was a kind of apotheosis of the political crisis in Tuva.

In 2006-2007 in Tuva, the main participants in political processes were the parties that coped with such functions as socio-political education and unity of citizens on the basis of common interests, explaining to the masses the political and socio-economic situation in which society lives, as well as the proposal for a platform of actions. The opposition was led by the former United Russia party members who were excluded by the decision of the political council of the Tuvinian regional branch of the All-Russian political party
"United Russia", then transferred to the "Rodina" party, and then to the "Russian Party of Life", the deputies of the Legislative Chamber of the Supreme Khural of the Republic of Tyva, former deputy Chairman of the Government who worked in the executive bodies of power for many years: V.M. Oiun, V.G. Val'kov, as well as the former prosecutor of the Republic of Tyva, deputy secretary of the political council of the regional branch of the "United Russia" party A.P. DambaKhuurak, representatives of the Russian Party of Life (RPL), the former mayor of Kyzyl Z.N. Sat, a surgeon, a deputy of the Legislative Chamber of the first convocation V.A. Ushkalov. As we can see, the opposition was headed by the representatives of the political elite of Tuva.

After a long political crisis that began in 2005 with the expression of mistrust in the Chairman of the Government R.T. Oorzhak by the deputies of the Legislative Chamber (the Parliament of Tuva) - in April 2007, at the first organizational session of the Legislative Chamber, through tremendous efforts on the part of the federal authorities, the members of the United Russia party elected V.M. Oiun as a Chairman of the Legislative Chamber. He was a member of the Fair Russia Party, a leader of the opposition that managed to shift the political processes in Tuva. Sh.V. Kara-ool, a leader of the Tuvinian "United Russia" party was invested in the authority of the Chairman of the Government of the Republic of Tuva. It became possible to agree on the "division" of portfolios and committees between "United Russia" and "Fair Russia" that won in the regional elections. Thus, two factions were formed comprising 20 and 12 deputies respectively (Doržu, Oiun, 2015: 223). As a result, the political hunger strike announced in March 2007 has achieved its main goal and contributed to the change of the political power in Tuva.

Subsequently, political hunger strikes have been announced more than once, protesting against the organization of the election process 
by the Parliament of the Republic, because of violations of the procedure for nominating and registration of candidates, conducting election campaigns and election results, which the opposition considered illegitimate. But these political hunger strikes have not given any serious results or changes, unlike the first one. The political hunger strikes in 1991 and 2007 will make it into history of Tuva not just as a kind of catalyst for changing the political course of power and a way of protest, but also as a form of struggle for the establishment of democratic rights and freedoms of the population.

\section{References}

Balakina, G.F. (1996). Ekonomika regiona v period reform: Respublika Tyva [Region's economy at the time of reforms: Republic of Tyva]. Novosibirsk, Nauka: p. 39.

Doržu, Z.Iu, Oiun, O.P. (2015). Mnogopartinost' v Tuve: genesis i stanovlenie (90-e gody XX nachalo XXI vv.) [Multi-party system in Tuva: Genesis and development (the 90's of the $20^{\text {th }}$ - early $21^{\text {st }}$ century)]. Kyzyl: RIO TuvGU, 258 p.

Obrashchenie k narodnym deputatam na Sessii Verkhovnogo Soveta Tuvinskoi ASSR [Address to the people's deputies at the session of the Supreme Soviet of the Tuvan ASSR]. In fond dokumental'nykh i pis'mennykh istochnikov natsional'nogo muzeia im. 60 bogatyrei [Fund of documentary and written sources of the National Museum named after 60 bogatyrs]. N-V., 782/3, p. 1.

"Obrashchenie k trudiashchimsia i molodezhi mnogonatsionalnoi Tuvy" uchastnikov i organizatorov politicheskoi golodovki [Address to workers and youth of multinational Tuva from participants and organizers of political hunger strike]. (February 8, 1991). In Molodezh' Tuvy [Young People of Tuva], p. 1.

Obrashchenie uchastnikov i organizatorov politicheskoi golodovki "Za zakonnost" vyborov i spravedlivuiu zhizn' k izbirateliam Respubliki [Address of the participants in political hunger strike "For the legitimacy of the elections and a fair life" to the voters of the Republic]. (March 30, 2007). In Tsentr Azii [Center Of Asia], 12.

Pokazateli sotsial'nogo i ekonomicheskogo razbitiia respubliki Tyva [Indicators of social and economic development of the Republic of Tuva] (1993). Kyzyl, p 50.

Spravka o proshedshei politicheskoi golodovke v g. Kyzyle s 28.01. po 8.02.1991g. [Reference on the political hunger strike in Kyzyl held from 28.01. till 8.02.1991], (signed by Salchak L.M., Deputy Director of the Museum). In Fond dokumental'nykh i pis'mennykh istochnikov natsional'nogo muzeia im. 60 bogatyrei [Fund of documentary and written sources of the National Museum named after 60 bogatyrs]. N-V., 782/9, p. 1. 


\title{
Политические голодовки в истории Тувы \\ как форма борьбы \\ за демократические права и свободы
}

\author{
О. Оюн \\ Тувинский государственный университет \\ Россия, 667000, Республика Тыва, Кызыл, \\ ул. Ленина, 36
}

\begin{abstract}
В статье изучается история первых политических голодовок в истории Тувы, инициированных и организованных представителями научной, творческой интеллигенции в 1991 и политической элиты в 2007 гг.

Актуальность темы исследования вызвана не только интересом историка изучить феномен политических головок, не свойственных менталитету тувинцев-кочевников, ранее не живиих при демократическом режиме, но необходимостью включить в научный оборот архивные материаль.

Рассматриваются причины голодовок, вызванные политическим кризисом в республике, неспособностью властей найти компромисс с идейными противниками и наладить диалог с обществом. Также анализируются позиция оппозиции и действующей исполнительной власти. Изучается сочиальный состав участников политических голодовок, их иели, задачи. Раскрываются последствия политических голодовок для ее участников. К примеру, когда участники политических голодовок и их жены в 1991 г. были лишены работы, они выжили благодаря клановой системе взаимопомощи, взаимовыручки родных и близких, характерной для тувинского традииионного общества. В 2006-2007 г2., в условиях политического кризиса в Туве, политические партии выполнили свою функиию быть посредником между обществом властью, доводя чаяния народа до исполнительной власти. Из политических голодовок власти извлекли урок, что для нормального функиионирования жизнедеятельности государства необходимо учитывать не только мнение большинства, оформленное в общественное мнение, но и мнение меньшинства, выраженное представителями творческой, научной, политической элит.
\end{abstract}

Ключевые слова: политическая голодовка, Республика Тыва, кочевники-тувинцьь, оппозиция.

Научная спеииальность: 24.00.01 - теория и история культуры. 